\title{
Eufemisme dalam Novel Buku Besar Peminum Kopi Karya Andrea Hirata
}

\author{
Anis Soraya \\ Universitas Muhammadiyah Jember \\ anissoraya98@gmail.com
}

DOI: https://doi.org/10.32528/bb.v6i1.4154

First received: 16-01-2021 Final proof received: 12-03-2021

\begin{abstract}
ABSTRAK
Penelitian ini bertujuan untuk mendeskripsikan bentuk dan fungsi eufemisme yang ada di dalam novel Buku Besar Peminum Kopi Karya Andrea Hirata. Jenis penelitian ini adalah deskriptif kualitatif. Data penelitian berupa kata, frasa dan kalimat yang mengandung gaya bahasa eufemisme. Teknik pengumpulan data yang digunakan adalah teknik membaca catat. Instrumen pengumpulan data adalah peneliti sendiri. Data dianalisis secara deskriptif dengan menggunakan model Milles dan Huberman melalui tiga tahapan yaitu, reduksi data, penyajian data, dan penarikan kesimpulan. Teknik pengujian keabsahan data menggunakan teknik peningkatan ketekunan. Hasil penelitian ini menunjukkan bahwa terdapat penggunaan bentuk eufemisme antara lain; bentuk singkatan, bentuk kata serapan, bentuk istilah asing, bentuk metafora dan bentuk perifrasis. Selain bentuk, ditemukan pula fungsi eufemisme antara lain; untuk kesopanan dan kenyamanan, untuk menghindari malapetaka, untuk menyamarkan makna, untuk mengurangi rasa malu, dan untuk melaksanakan perintah agama. Makna dari hasil penelitian ini adalah penggunaan eufemisme dapat mengurangi konflik-konflik yang timbul akibat kesalahpahaman dalam berkomunikasi atau penyampaian informasi. Selain itu, dapat membantu para pembaca untuk lebih mudah dalam memahami nilai-nilai budaya dalam bahasa. Dengan adanya eufemisme didalam novel, dapat menambah kecakapan pengarang dalam memainkan gaya bahasa sesuai konteks yang mengikutinya, sehingga dapat menumbuhkan sikap toleransi bagi para pembaca.
\end{abstract}

Kata kunci: eufemisme; bentuk; fungsi; bahasa; novel.

\begin{abstract}
This study aims to describe the form and function of euphemisms in Andrea Hirata's novel The Big Book of Coffee Drinkers. This type of research is descriptive qualitative. The research data are in the form of words, phrases and sentences that contain euphemistic language styles. The data collection technique used was note reading technique. The data collection instrument is the researcher himself. Data were analyzed descriptively using the Milles and Huberman model through three stages,
\end{abstract}


namely, data reduction, data presentation, and conclusion drawing. The technique of testing the validity of the data uses the technique of increasing persistence. The results of this study indicate that there are uses of euphemisms, among others; abbreviated forms, loan words, foreign terms, metaphorical forms and perifratic forms. Apart from form, the functions of euphemisms are also found, among others; for modesty and comfort, to avoid calamity, to disguise meaning, to reduce shame, and to carry out religious orders. The meaning of the results of this study is that the use of euphemisms can reduce conflicts arising from misunderstandings in communicating or delivering information. In addition, it can help readers to more easily understand cultural values in language. With the existence of euphemisms in the novel, it can increase the author's ability to play a language style according to the context that follows it, so that it can foster an attitude of tolerance for readers.

Keywords: euphemisms; shape; function; language; novel

\section{PENDAHULUAN}

Bahasa menjadi wadah penting dalam kehidupan manusia. Menurut Omar (dalam Khalidi, 2017:89), bahasa yang kita gunakan merupakan lambang dalam mengaitkan maksud atau pikiran manusia dengan perkara yang konkrit ataupun yang abstrak. Selanjutnya, pengguna bahasa dapat mengerti tentang perkara yang dibicarakan. Pengguna bahasa harus memiliki ketrampilan dalam berbahasa supaya bahasa yang digunakan sesuai dengan apa yang ingin dibicarakan, dengan siapa berbicara dan bagaimana situasi sewaktu berbicara. Pengguna bahasa perlu bijak dalam memilih bentuk bahasa supaya menepati ciri-ciri penggunaan bahasa yang beretika, sopan dan beradab. Terdapat banyak jenis gaya bahasa yang dapat melambangkan etika dan kesopansantunan, salah satunya eufemisme.

Eufemisme yaitu salah satu gaya bahasa yang masuk pada subjenis perbandingan. Menurut Santoso (2016), gaya bahasa perbandingan ialah ungkapan kias yang menyatakan perbandingan untuk meningkatkan pengaruh dan kesannya pada pembaca atau pendengarnya. Gaya bahasa yang indah berfungsi untuk meningkatkan kesan melalui jalan memperkenalkan dan membandingkan suatu benda atau hal lainnya yang lebih umum (Tarigan, 2013:4). Menurut Keraf (2016:132), eufemisme seperti acuan berupa ungkapan-ungkapan yang tidak menyinggung perasaan orang, atau ungkapan-ungkapan yang halus untuk menggantikan ungkapan yang mungkin dirasa kasar, menghina atau menyugestikan sesuatu yang tidak menyenangkan. Menurut Sutarman (2017:50), eufemisme adalah ungkapan yang dinilai lebih halus, sopan, dan aman untuk mengganti ungkapan yang dinilai tidak sopan atau diketahui dapat menimbulkan bahaya. Penggunaan eufemisme memiliki bentuk dan fungsi.

Menurut Allan (dalam Saputri, 2019:199), eufemisme memiliki delapan fungsi yaitu (1) menghindari kata-kata yang dapat menimbulkan kepanikan atau ketakutan, (2) tidak merendahkan seseorang, (3) tidak menyinggung hal-hal yang menyakiti, (4) bertujuan retoris, (5) menggantikan ungkapan yang dilarang, tabu, dan bercitra negatif, (6) merahasiakan sesuatu, (7) menghormati atau menghargai orang lain, dan (8) tidak menyindir atau mengkritik. Berdasarkan beberapa pengertian di atas, dapat peneliti 
simpulkan bahwa eufemisme merupakan suatu ungkapan halus sebagai pengganti ungkapan kasar atau tabu yang memiliki fungsi sesuai konteks yang mengikutinya. Baik untuk menjaga perasaan orang lain, menghindari rasa malu atau hal-hal buruk lainnya. Misalnya saja saat seseorang sedang menghadapi situasi perselisihan, menyakitkan, pergaduhan atau marah, penggunaan eufemisme dapat digunakan supaya pengguna bahasa masih terlihat dapat mencerminkan nilai-nilai kesantunan dalam berbahasa.

Menurut Eka (2016:1), Eufemisme merupakan salah satu gaya bahasa yang berperan penting dalam interaksi sosial, terutama untuk menjaga keharmonisan suatu hubungan. Hal tersebut disebabkan eufemisme berfungsi untuk mengganti ungkapan yang bermakna kasar dengan ungkapan yang lebih halus. Dengan menggunakan eufemisme pula, seorang penulis bisa menyampaikan pesan dengan lebih beretika, santun, dan sopan. Dalam kehidupan sehari-hari, eufemisme banyak digunakan oleh berbagai kalangan masyarakat dengan berbagai tujuan. Misalnya pada kalangan politisi, ungkapan diamankan digunakan untuk menghaluskan kata ditangkap yang berfungsi untuk kenyamanan sehingga terdengar lebih sopan. Eufemisme bukan hanya sebagai penghalusan bahasa, tetapi juga melatih kecerdasan masyarakat untuk menginterpretasikan ungkapan yang muncul berdasarkan kenyataan serta mengetahui makna yang ada di balik ungkapan eufemisme itu. Pada penelitian ini, peneliti akan mengkaji eufemisme menggunakan sumber data dalam bentuk karya sastra berupa novel.

Menurut Dibia, (2018:76), novel merupakan cerita panjang mengenai kehidupan, sifatnya dapat berupa fiktif maupun non fiktif. Bahasa yang digunakan dalam sebuah novel, tentunya sebagai penyampai informasi kepada penikmat maupun pembacanya. Selain itu, bahasa novel juga dapat melambangkan hal-hal seperti penggunaan eufemisme. Dalam menulis sebuah novel, setiap pengarang memiliki ciri khas masingmasing dalam memainkan gaya bahasa yang digunakan. Salah satunya adalah Andrea Hirata, yang terkenal dengan berbagai macam gaya bahasa yang digunakan dalam setiap karyanya. Seperti salah satu novelnya yang berjudul Buku Besar Peminum Kopi, didalamnya banyak mengandung gaya bahasa eufemisme. Pengarang menggunakan eufemisme di dalam novel sebagai strategi untuk mengganti ungkapan kasar menjadi halus dan mengganti kata tabu menjadi lebih pantas. Selain itu, penggunaan eufemisme dalam novel juga dapat mengaburkan makna yang ingin disampaikan oleh pengarang. Misal, saat pengarang menggambarkan salah satu kondisi tokoh yang mengalami cacat seperti bisu dan tuli, pengarang akan mengganti ungkapan yang lebih halus dengan istilah tunawicara dan tunarungu. Fungsi eufemisme yang digunakan oleh pengarang, bertujuan agar cerita terkesan lebih sopan sekaligus tidak menyinggung atau menyakiti hati pembaca yang mungkin memiliki kondisi sama seperti yang disampaikan dalam cerita sebuah karya sastra.

Penelitian tentang eufemisme sangat penting dan memiliki banyak manfaat, salah satunya bagi guru. Pertama, bagi guru Bahasa Indonesia dapat dijadikan bahan referensi saat mengajar khususnya materi unsur intrinsik pada bagian gaya bahasa. Kedua, guru dapat memberi contoh kepada siswa untuk menerapkan eufemisme saat kegiatan diskusi di kelas. Ketiga, gaya bahasa eufemisme dapat diterapkan guru saat menulis atau menciptakan suatu karya sastra. Sumber data yang peneliti gunakan dalam penelitian ini 
adalah Novel yang berjudul Buku Besar Peminum Kopi Karya Andrea Hirata. Novel ini adalah salah satu novel best seller yang merupakan edisi asli dari novel Maryamah Karpov dan kisah-kisah dalam novel Padang Bulan serta Cinta di Dalam Gelas yang sebelumnya diterbitkan secara terpisah. Novel ini terbit pertama kali tahun 2020 oleh Benteng Pustaka, di Yogyakarta setebal 350 halaman. Sampul buku ini berwarna abu-abu kebiruan dengan dilengkapi sebuah gambar cangkir kopi kuno berwarna putih.

Novel ini menceritakan tokoh Maryamah yang bercita-cita ingin menjadi guru. Namun, impiannya kandas setelah ayahnya meninggal dunia, dan Ia harus bekerja demi menghidupi ibu serta adik-adiknya. Kemudian diceritakan juga kisah Ikal yang merupakan mahasiswa S3 jurusan Ekonomi Telekomunikasi lulusan Sheffield Hallam University di Inggris yang tak kunjung mendapatkan pekerjaan akibat terjadinya krisis moneter, akhirnya harus kembali ke kampung halamannya dan terpaksa bekerja di warung kopi milik pamannya. Selanjutnya menceritakan tokoh Salamot, yang baru beberapa hari menikah tetapi sudah ditinggal oleh suaminya dan tak kunjung kembali. Akhirnya setelah dewasa, ketiga tokoh ini saling bertemu dan menjadi sahabat. Setelah itu ada sebuah tugas yang harus ditanggung oleh Ikal yaitu, harus membantu Maryamah memenangkan pertandingan catur saat 17 Agustus. Maryamah harus mengalahkan juara catur selama dua tahun berturut-turut yang sekaligus mantan suaminya. Namun, dengan usaha dan latihan keras serta cobaan yang bertubi-tubi, akhirnya Maryamah dapat memenangkan pertandingan catur yang diikutinya.

Alasan peneliti memilih novel Buku Besar Peminum Kopi Karya Andrea Hirata yaitu; pertama, karena novel ini banyak mengandung makna konotatif berupa ungkapan eufemisme yang sebenarnya masih memiliki makna asli yang dapat lebih mudah dipahami oleh pembaca dan kedua, novel ini belum pernah dikaji atau diteliti sebelumnya. Penelitian ini, hanya berfokus pada bentuk dan fungsi eufemisme. Menurut Sutarman (2017:66), penggunaan eufemisme dapat dibentuk dengan lima cara yaitu (1) penggunaan singkatan, (2) kata serapan, (3) istilah asing, (4) metafora, dan (5) perifrasis. Kemudian, Rubby dalam Setiawaty (2018:89) menambahkan 3 bentuk eufemisme yaitu (1) ekspresi figuratif, (2) satu kata untuk menggantikan kata yang lainnya, dan (3) bentuk akronim. Sedangkan jika dilihat dari fungsinya, penggunaan eufemisme memiliki lima fungsi yaitu, (1) untuk kesopanan dan kenyamanan, (2) untuk menghindari malapetaka, (3) untuk menyamarkan makna, (4) untuk mengurangi rasa malu, dan (5) untuk melaksanakan perintah agama (Sutarman 2017:110).

Penelitian tentang eufemisme pernah dilakukan peneliti terdahulu, yaitu (1) oleh Supriyadi, (2013). Perbedaan dengan peneliti saat ini ialah; pertama, Supriyadi mengkaji tabu bahasa dan eufemisme sedangkan peneliti saat ini hanya mengkaji eufemisme. Kedua, sumber data Supriyadi berupa kumpulan cerpen yang berjudul Senyum Karyamin Karya Ahmad Tohari sedangkan peneliti saat ini berupa novel yang berjudul Buku Besar Peminum Kopi Karya Andrea Hirata. Ketiga, data eufemisme yang ditemukan Supriyadi lebih dominan Bahasa Jawa sedangkan data yang ditemukan peneliti saat ini dominan Bahasa Indonesia dan istilah Asing. Selanjutnya, peneliti terdahulu ke (2) oleh Puspitasari, (2019). Perbedaan dengan peneliti saat ini ialah; pertama, sumber data yang digunakan adalah surat kabar Solopos sedangkan peneliti saat ini menggunakan sumber 
data novel Buku Besar Peminum Kopi Karya Andrea Hirata. Kedua, teknik analisis yang digunakan Puspitasari teknik analisis mengalir sedangkan peneliti saat ini menggunakan teknik analisis model Milles dan Huberman yaitu, reduksi data, penyajian, data, dan penarikan kesimpulan.

\section{METODE PENELITIAN}

Metode yang digunakan dalam penelitian ini adalah metode deskriptif kualitatif. Dengan metode deskriptif, seorang peneliti sastra dituntut mengungkap fakta-fakta yang tampak atau data dengan cara memberi deskripsi (Siswantoro, 2016:57). Penggunaan metode ini bertujuan untuk mendeskripsikan bentuk dan fungsi eufemisme dalam novel Buku Besar Peminum Kopi Karya Andrea Hirata. Penelitian sastra memerlukan data yaitu berwujud kata, frasa, atau kalimat (Siswantoro, 2016:70). Data Penelitian ini berupa kata, frasa, dan kalimat yang mengandung gaya bahasa eufemisme. Sumber data berhubungan dengan subjek penelitian dari mana data diperoleh (Siswantoro, 2016:72). Dalam memilih sumber data harus sesuai dengan ketepatan, kelayakan dan kedalaman informasi yang diperoleh (Nugrahani, 2014:108). Sumber data dalam penelitian ini berupa novel yang berjudul Buku Besar Peminum Kopi Karya Andrea Hirata.

Teknik pengumpulan data dalam penelitian ini menggunakan dokumen. Dokumen yang dimaksud dalam penelitian ini adalah novel Buku Besar Peminum Kopi Karya Andrea Hirata. Metode pengumpulan data dalam penelitian ini adalah metode simak dengan teknik lanjut catat. Metode simak yang dimaksud yaitu, peneliti membaca secara keseluruhan isi cerita pada novel Buku Besar Peminum Kopi Karya Andrea Hirata untuk mencari dan menemukan data berupa ungkapan yang mengandung gaya bahasa eufemisme. Sedangkan teknik lanjut catat yang dilakukan adalah mencatat data yang telah ditemukan oleh peneliti. Adapun tahap-tahap yang dilakukan dalam mengumpulkan data yaitu; (1) membaca dan memahami inti keseluruhan novel Buku Besar Peminum Kopi Karya Andrea Hirata (2) menandai bagian yang menjadi data penelitian, dan (3) mencatat data penelitian yang telah ditemukan.

Instrumen berarti alat yang digunakan untuk mengumpulkan data (Siswantoro, 2016:73). Instrumen dalam penelitian ini adalah peneliti sendiri. Teknik analisis data pada penelitian ini menggunakan model Miles dan Huberman yang dibagi menjadi tiga tahapan yakni, (1) reduksi data, (2) penyajian data, dan (3) penarikan kesimpulan. Tahap reduksi adalah suatu proses pemilihan data yang telah didapat dari novel. Tahap reduksi pada penelitian ini, ungkapan yang mengandung eufemisme dan diberi kode untuk membuat kategori dan memilih serta memilah data yang tidak diperlukan kemudian dibuang. Selanjutnya data yang terkumpul dan sudah dikategorikan, disajikan menjadi suatu bentuk pola-pola. Tahapan ini disebut dengan tahap penyajian data yang bertujuan untuk mempermudah penarikan kesimpulan. Data penelitian ini disajikan dengan bentuk narasi dekriptif. Tahap yang terakhir yakni, tahap penarikan kesimpulan yang dilakukan untuk mengetahui apakah data yang telah direduksi dan disajikan telah sesuai dengan fokus penelitian. Tujuan dari verifikasi ialah untuk memastikan apakah data yang didapat merupakan data jenuh. Sedangkan Teknik pengujian kesahihan data yang digunakan dalam penelitian ini ialah teknik peningkatan ketekunan, yaitu dengan membaca, 
mengurai, dan mengamati lebih dalam serta intensif pada novel Buku Besar Peminum Kopi Karya andrea Hirata sebagai sumber data penelitian. Teknik ini dipilih karena didasarkan pada metode yang digunakan dalam penelitian ini, yakni metode telaah dokumen, sehingga yang dilakukan oleh peneliti untuk menguji tingkat kesahihan data ialah dengan cara meningkatkan ketekunan dalam menelaah novel.

\section{HASIL DAN PEMBAHASAN}

Eufemisme merupakan ungkapan halus sebagai pengganti ungkapan kasar atau tabu yang memiliki fungsi sesuai konteks yang mengikutinya. Pengarang menggunakan eufemisme didalam novel sebagai strategi untuk mengganti ungkapan kasar menjadi halus dan mengganti kata tabu menjadi lebih pantas. Selain itu, penggunaan eufemisme dalam novel juga dapat mengaburkan makna yang ingin disampaikan pengarang pada pembaca. Berikut hasil analisis data yang peneliti temukan berdasarkan bentuk dan fungsi eufemisme dalam novel Buku Besar Peminum Kopi Karya Andrea Hirata.

\section{a) Bentuk Eufemisme dalam Novel Buku Besar Peminum Kopi Karya Andrea Hirata}

\section{1) Bentuk Singkatan}

Singkatan adalah bentuk umum pemendekan kata atau beberapa kata menjadi satu deretan huruf. Salah satu jenis singkatan yaitu inisialen. Inisialen merupakan bentuk singkatan dari beberapa kata yang dibentuk dengan mengambil huruf awal tiap kata menjadi satu deretan huruf (Sutarman, 2017:67). Penggunaan singkatan jenis inisialen memiliki 3 fungsi yaitu; (1) lebih praktis dan ekonomis, (2) menghasilkan istilah yang unik, dan (3) lebih menghaluskan makna kata yang di singkat (Sutarman, 2017:68). Bentuk penggunaan singkatan dapat peneliti temukan pada kutipan berikut:

(1BS) "Mereka adalah buruh perantau, penduduk asli pulau kami yang bekerja di pabrik kota-kota Sumatra dan Jawa. Pabrik-pabrik itu kolaps akibat krisis ekonomi lalu mereka kena PHK." (Hal:100).

Pada kutipan data (1BS) ditemukan bentuk eufemisme singkatan yaitu PHK. Berdasarkan teori Sutarman, singkatan $\boldsymbol{P H K}$ ini masuk pada jenis inisialen karena singkatan yang dibentuk dengan mengambil huruf awal dari tiap kata. $\boldsymbol{P H K}$ pemendekan dari Pemutusan Hubungan Kerja. Jika dilihat dari fungsinya, singkatan PHK ini masuk pada fungsi yang ketiga yaitu, lebih menghaluskan makna kata yang di singkat. Dikatakan menghaluskan makna karena istilah $\boldsymbol{P H}$ ini memiliki arti kasar yaitu dipecat. Singkatan $\boldsymbol{P H K}$ mengacu pada aktivitas yang menyangkut kebijakan pemerintah.

Pada kutipan data (1BS), tokoh Ikal mengatakan pada sahabatnya bahwa, akibat dari krisis moneter para buruh perantau yang bekerja di pabrik kota harus pulang kampung karena terkena $P H K$. Sebutan $\boldsymbol{P H K}$ lebih halus dan sopan daripada kata dipecat untuk menjaga etika dalam berkomunikasi. Pengarang menggunakan gaya bahasa eufemisme berupa singkatan $\boldsymbol{P H K}$ untuk mengajarkan kepada pembaca agar dapat lebih bijak dalam memilah dan memilih bahasa yang cocok digunakan agar tidak menyakiti hati orang lain sehingga komunikasi dapat berjalan dengan baik. 


\section{2) Bentuk Kata Serapan}

Menurut Sutarman (2017:76) istilah "serapan" pada hakikatnya mengacu pada hal yang sama yaitu menyerap atau mengambil kata/ istilah dari bahasa asing maupun bahasa daerah. Berdasarkan prosesnya, ada dua jenis kata serapan yakni kata serapan adopsi dan adaptasi. Kata serapan adopsi adalah proses terserapnya bahasa asing ke dalam bahasa Indonesia dengan mengambil keseluruhan kata. Sedangkan kata serapan adaptasi mengalami perubahan penulisan, lafal, dan ejaan. Menurut Sutarman (2017:76), penggunaan kata serapan bahasa Indonesia dilatarbelakangi oleh tiga alasan yaitu; (1) adanya istilah asing tertentu yang tidak dapat ditemukan padanan katanya dalam bahasa Indonesia, (2) untuk mengurasi pemborosan kata, (3) memiliki nilai eufemistis yang tinggi karena makna kata lebih disamarkan. Bentuk penggunaan kata serapan dapat peneliti temukan pada kutipan berikut:

(2BKS) "Kini aku mengerti mengapa motor ini tampak seperti lukisan abstrak." (Hal:146).

Pada kutipan data (2BKS) ditemukan bentuk eufemisme kata serapan yaitu abstrak yang merupakan hasil serapan dari bahasa Inggris yaitu abstract. Berdasarkan teori Sutarman, kata abstrak masuk pada jenis kata serapan adaptasi karena mengalami perubahan penulisan (abstract-abstrak). Jika dilihat dari alasannya, kata serapan abstrak masuk pada alasan ketiga yaitu, memiliki nilai eufemistis yang tinggi karena makna kata lebih disamarkan. Menurut KBBI, kata abstrak memiliki arti tidak berwujud, tidak berbentuk.

Pada kutipan data (2BKS), tokoh Ikal digambarkan sedang membeli sebuah motor vespa di dealer. Saat bertanya harga kepada penjual, didapatkan jawaban bahwa harga motor tersebut murah. Mendengar jawaban tersebut, akhirnya Ikal pun paham mengapa motor tersebut terlihat seperti lukisan abstrak. Jadi, maksud kata abstrak pada kutipan data di atas adalah sebuah motor bekas yang memiliki kondisi kurang baik. Pengarang menggunakan eufemisme kata serapan abstrak pada kutipan diatas untuk mengajarkan kepada pembaca untuk tidak perlu mengatakan apa yang dilihatnya buruk dengan bahasa yang dapat menyinggung perasaan orang lain. Pada data diatas, memberikan contoh penggunaan eufemisme untuk proses jual beli. Apabila sesuatu yang akan kita beli tidak cocok, bisa menolak dengan cara halus agar penjual tidak tersinggung.

\section{3) Penggunaan Istilah Asing}

Menurut Sutarman (2017:78), penggunaan istilah asing merupakan penggunaan bahasa asing pada tingkat satuan kata, frasa, maupun klausa dalam konteks kalimat maupun wacana yang menggunakan bahasa Indonesia, baik secara lisan maupun tertulis. Bentuk penggunaan istilah asing dapat peneliti temukan pada kutipan berikut:

(3BIA) "Cita-cita M. Nur di sekolah dulu ingin menjadi detektif. Barangkali karena dia jengkel dengan mereka yang suka mengejeknya. Dia drop out saat kelas 2 SMP” (Hal:99).

Pada kutipan data (3BIA) ditemukan bentuk eufemisme istilah asing dari bahasa Inggris yaitu drop out yang memiliki arti keluar. Karena istilah keluar dari sekolah 
merupakan tindakan yang buruk, maka pengarang menggunakan eufemisme agar tidak terkesan terang-terangan. Pada kutipan data (3BIA), tokoh Ikal menceritakan kepada sahabatnya tentang pendidikan Nur yang tidak lulus dari bangku SMP. Nur memutuskan keluar dari sekolah karena jengkel dengan teman-teman yang mengejek dirinya sebagai anak pendek. Dengan penulisan eufemisme istilah asing yang digunakan pengarang, mengajarkan kepada pembaca untuk tidak mudah mengartikan segala sesuatu secara buruk. Alangkah baiknya pahami terlebih dahulu latar belakang atau sebab akibat dari kata atau istilah yang dibaca atau didengar.

\section{4) Penggunaan Metafora}

Metafora adalah semacam analogi yang membandingkan dua hal secara langsung, tetapi dalam bentuk yang singkat (Keraf, 2016:139). Jadi, dapat diartikan metafora adalah pemakaian kata atau kelompok kata bukan dengan arti sebenarnya, melainkan sebagai lukisan berdasarkan persamaan/ perbandingan. Bentuk penggunaan metafora dapat peneliti temukan pada kutipan berikut:

(4BM) "Selanjutnya ku saksikan sendiri usaha-usaha gulung tikar dan ribuan orang kehilangan pekerjaan” (Hal:42).

Pada kutipan data (4BM) ditemukan bentuk eufemisme metafora gulung tikar. Sesuai dengan teori yang dijelaskan diatas, bahwa metafora bukanlah pemakaian kata yang sesuai dengan arti sebenarnya. Maksudnya, arti dari gulung tikar bukanlah suatu benda berupa tikar/karpet yang dapat digulung, namun makna sebenarnya ialah ditutupnya usaha yang dimiliki. Pada kutipan data (4BM) tokoh Nong bercerita pada temannya saat dirinya merantau ke kota untuk mencari kerja. Bukannya mendapatkan pekerjaan, Nong malah melihat banyak pengusaha yang gulung tikar akibat krisis moneter. Istilah gulung tikar lebih cocok digunakan untuk mengganti makna sebenarnya yaitu bangkrut. Pengarang menggunakan bentuk metafora berupa gulung tikar, untuk mengajarkan kepada pembaca agar dapat memilih bahasa yang cocok digunakan sesuai situasi dan kondisi. Mengganti kata bangkrut dengan istilah gulung tikar sudah menunjukkan bahwa kita sebagai makhluk sosial memiliki rasa simpati dengan ikut prihatin terhadap musibah yang menimpa orang lain.

\section{5) Penggunaan Perifrasis}

Perifrasis adalah mengungkapkan kembali makna suatu teks secara tertulis maupun lisan dengan menggunakan kata-kata atau kalimat yang lebih panjang dari teks aslinya. (Sutarman, 2017:85). Jadi, penggunaan perifrasis harus tetap mempertahankan urutan ide dari pengarang sesuai dengan teks aslinya dan tidak boleh menghadirkan sesuatu yang baru. Bentuk penggunaan perifrasis dapat peneliti temukan pada kutipan berikut:

(5BP) "Bahkan cinta, juga amat sederhana disana. Sepasang remaja yang telah akil baliq dipasang-pasangkan orang tua mereka lalu dinikahkan secara islam” (Hal:88).

Pada kutipan data (5BP) ditemukan bentuk eufemisme perifrasis yaitu dinikahkan secara islam. Data tersebut dikatakan parafrasis karena dituliskan dengan kalimat yang 
lebih panjang dari makna aslinya yaitu, nikah siri. Pada kutipan data (5BP) pengarang menceritakan pada pembaca bahwa di sebuah pulau kecil dengan kehidupan yang sangat tertinggal, anak-anak yang masih dibawah umur tetapi sudah akil baliq dijodohkan oleh orangtuanya dan kemudian dinikahkan secara islam. Ungkapan dinikahkan secara islam dikatakan eufemisme karena dirasa lebih halus dan terhormat saat diucapkan dan didengar daripada nikah siri. Sebab, sudah dipercaya oleh masyarakat apabila nikah siri, pihak wanita tidak dapat menuntut hak apapun dari laki-laki. Pengarang menggunakan perifrasis untuk mengajarkan kepada pembaca agar dapat memilih bahasa yang sekiranya dapat menghormati orang lain. Makna yang dapat diambil dari data (5BP), akibat dari tidak adanya pendidikan serta rendah pengetahuan, membuat masyarakat melanjutkan tradisi yang salah secara turun temurun, yaitu melakukan pernikahan secara dini.

\section{b) Fungsi Eufemisme dalam Novel Buku Besar Peminum Kopi Karya Andrea Hirata \\ 1) Untuk Kesopanan dan Kenyamanan}

Kesopanan adalah upaya yang dilakukan agar dinilai positif orang lain melalui sikap, perbuatan, perkataan, maupun penampilan (Sutarman, 2017:110). Kesopanan berkembang menjadi sebuah norma yang berlaku di masyarakat. Norma kesopanan salah satunya dibentuk melalui perkataan yang ditujukan kepada orang lain. Fungsi kesopanan dan kenyamanan dapat peneliti temukan pada kutipan berikut:

(1SKK) "Karena kondisi kandung kemihnya itu, Paman tak bisa berteriak, dan itu siksaan yang hebat baginya sebab dia sangat senang berteriak-teriak marah" (Hal:83).

Pada kutipan data (1SKK), tokoh Ikal menceritakan kepada pembaca tentang kondisi pamannya yang memiliki penyakit kandung kemih. Kandung kemih adalah bagian dari sistem saluran kencing yang terdapat di dalam tubuh manusia. Maka dari itu, pengarang menggunakan istilah kandung kemih agar terdengar lebih sopan dan nyaman. Selain itu, yang diceritakan Ikal adalah kondisi pamannya yang berusia lebih tua, jadi pengarang menggunakan istilah yang sopan dalam menyebut sebuah penyakit dan juga menghormati orang yang lebih tua. Dengan adanya eufemisme seperti data (1SKK), dapat mengajarkan kepada pembaca agar dapat lebih bijak dalam memilih suatu ungkapan yang akan disampaikan kepada orang lain. Dengan menggunakan eufemisme, artinya seseorang sudah dapat menerapkan norma kesopan-santunan dalam berkomunikasi.

\section{2) Untuk Menghindari Malapetaka}

Sebuah kata pada dasarnya adalah sebuah harapan. Kata-kata mempunyai kekuatan doa yang didengar oleh Tuhan. Keyakinan untuk menghindari perkataan yang tidak baik dengan tujuan menghindari malapetaka semakin banyak dilakukan. Menurut Sutarman, (2017:111), seseorang tidak boleh mengucapkan perkataan yang ada tendensi kesombongan, cacian, makian, kutukan, sumpah sarapah karena perkataan yang buruk diyakini menjadi kenyataan dan menimbulkan malapetaka. Fungsi eufemisme untuk menghindari malapetaka dapat peneliti temukan pada kutipan berikut: 
(2SMM) "Kurasa seperti pandangan ibuku tentang bekerja, mematuhi seorang ibu juga punya realm sendiri bagi seorang anak” (Hal:89).

Pada data (2SMM) ditemukan eufemisme mematuhi seorang ibu yang memiliki makna tidak durhaka atau melawan orangtua. Sependapat dengan Sutarman yang mengatakan bahwa, setiap kata punya kekuatan doa yang didengar oleh Tuhan. Pada data ini, menceritakan tentang Ikal yang tak kunjung mendapat pekerjaan di kota akibat terjadinya krisis moneter. Akhirnya, ibunya mengirim surat dan menyuruh Ikal pulang ke kampung halaman dan ikut bekerja pada pamannya. Menurut ibunya, ini adalah pilihan terbaik daripada tidak bekerja sama sekali. Kemudian Ikal berpikir, bahwa yang dikatakan ibunya memang benar. Mematuhi ibu adalah bentuk bakti kepada orangtua. Jika Ikal membantah dan tidak menuruti perkataan ibunya, Ia takut sesuatu buruk terjadi padanya karena apa yang dipilihnya tidak mendapat restu dari ibu. Jadi, fungsi eufemisme pada data (2SMM) adalah untuk menghindari malapetaka. Dari pembahasan diatas dapat dimaknai bahwa, anak harus patuh pada orangtua selagi itu tidak menyesatkan diri kita. Sebab, restu dan doa orangtua adalah pintu utama dalam mempermudah urusan kita.

\section{3) Untuk Menyamarkan Makna}

Menurut Sutarman (2017:112), tidak semua kata pantas di dengar berdasarkan makna aslinya. Oleh karena itu, kata-kata tertentu perlu disamarkan dengan ungkapan lain agar maknanya tidak diketahui secara langsung oleh orang lain. Fungsi eufemisme untuk menyamarkan makna dapat peneliti temukan pada kutipan berikut:

(3SMMK) "Sehubungan dengan situasi yang kurang menguntungkan itu, maka untuk sementara ini Ananda kiranya belum mendapat kesibukan baru.” (Hal:45).

Pada kutipan data (3SMMK), ditemukan eufemisme belum mendapat kesibukan baru yang memiliki maksud menganggur atau tidak memiliki pekerjaan. Pada data ini, menceritakan tokoh Ikal yang sedang menulis surat untuk ibunya dan memberitahukan bahwa dirinya belum mendapatkan pekerjaan. Namun, Ikal menulis dengan bahasa belum mendapat kesibukan baru karena dirasa lebih halus agar ibunya tidak langsung terkejut saat membaca surat darinya. Dengan demikian, fungsi eufemisme pada data (3SMMK) adalah untuk menyamarkan makna. Berdasarkan analisis data (3SMMK), dapat dimaknai bahwa dalam mengungkapkan sesuatu kepada orang lain baik secara lisan maupun tertulis harus selektif dalam memilih kata-kata yang tepat agar tidak membuat orang lain merasa kecewa mendengar kabar yang kurang baik dari kita.

\section{4) Untuk Mengurangi Rasa Malu}

Menurut Sutarman (2017:113), eufemisme digunakan sebagai upaya untuk mengurangi efek rasa malu yang terjadi pada korban kekerasan ataupun pelecehan seksual. Fungsi eufemisme untuk mengurangi rasa malu dapat peneliti temukan pada kutipan berikut:

(4SMRM) "karena suatu penyakit kandung kemih yang aneh membuatnya tak bisa menampilkan suatu performa pada tingkat paling minimal sekalipun.” (Hal:83). 
Pada kutipan data (4SMRM) ditemukan eufemisme performa pada tingkat paling minimal yang bermakna melakukan hubungan seksual. Pada data ini, pengarang menceritakan tentang kondisi paman yang memiliki penyakit kandung kemih hingga tidak mampu lagi melakukan hubungan seksual. Pengarang menggunakan kata performa untuk mengganti hubungan seksual adalah untuk mengurangi rasa malu pada tokoh Paman. Makna yang dapat diambil dari pembahasan data (4SMRM) adalah gunakan bahasa yang baik untuk mengganti bahasa yang dirasa tabu atau kurang pantas didengar untuk menjaga perasaan agar orang yang bersangkutan tidak merasa malu.

\section{5) Untuk Melaksanakan Perintah Agama}

Setiap kata harus diperhitungkan baik buruknya jangan sampai membuat orang lain tersinggung atau marah. Bertutur kata dengan lemah lembut serta pemilihan kata yang tepat akan mendatangkan pahala jika dilakukan dengan ikhlas (Sutarman, 2017:114). Fungsi eufemisme untuk melaksanakan perintah agama dapat peneliti temukan pada kutipan berikut:

(5SMPA) "Selendang pembatas bukan muhrim di pasang. Juri menenangkan penonton, pertandingan di mulai". (Hal:160).

Pada kutipan data (5SMPA) ditemukan eufemisme Selendang pembatas bukan muhrim. Maksudnya adalah selendang pembatas yang digunakan oleh dua orang pemain catur yaitu Maryamah dan lawannya yang bejenis kelamin laki-laki. Selendang itu wajib ditutup saat pertandingan dimulai karena dua pemain bukan suami istri atau saudara yang tidak boleh saling bertatapan secara dekat. Jadi, fungsi selendang ditutup adalah untuk melaksanakan perintah agama. Makna yang dapat diambil dari hasil pembahasan data (5SMPA) adalah untuk melaksanakan perintah agama, dapat kita lakukan dengan cara dan ungkapan yang tepat agar pahala baik selalu kita terima.

\section{SIMPULAN}

Berdasarkan hasil analisis data di atas, dapat peneliti simpulkan bahwa penggunaan eufemisme sangat penting ada dalam sebuah novel. Saat pembaca mampu memahami bentuk dan fungsi eufemisme dari novel Buku Besar Peminum Kopi Karya Andrea Hirata, maka pembaca akan mendapat pengetahuan baru terutama dalam hal berbahasa. Fungsi dari penggunaan eufemisme sangat bermanfaat untuk membiasakan berbicara sopan, tidak sembarang berucap agar terhindar dari malapetaka, menyamarkan makna dari sesuatu yang tidak pantas didengar secara langsung, mengurangi rasa malu, dan melaksanakan perintah agama. Penggunaan eufemisme dapat mengurangi konflik-konflik yang timbul akibat kesalahpahaman dalam berkomunikasi atau penyampaian informasi. Selain itu, dapat membantu para pembaca untuk lebih mudah dalam memahami nilai-nilai budaya dalam bahasa. Dengan adanya eufemisme didalam novel, dapat menambah kecakapan pengarang dalam memainkan gaya bahasa sesuai konteks yang mengikutinya, sehingga dapat menumbuhkan sikap toleransi bagi para pembaca. 


\section{UCAPAN TERIMAKASIH}

Peneliti ucapkan terimakasih kepada Dr. Fitri Amilia, S.S., M.Pd. selaku dosen pengampu matakuliah menulis artikel yang telah membimbing dengan baik dalam menyelesaikan tugas penelitian ini. Peneliti juga mengucapkan terimakasih kepada teman-teman yang telah berkontribusi memberikan pendapat dan saran dalam penyusunan penelitian ini.

\section{DAFTAR PUSTAKA}

Dibia, I. (2018). Apresiasi Bahasa dan Sastra Indonesia. Depok: Rajagrafindo Persada. Eka, W. (2016). Eufemisme dalam Wacana Konflik Suriah pada Blog Kajian Timur Tengah. Doctoral Dissertation, Universitas Andalas.

Hirata, A. (2020). Buku Besar Peminum Kopi. Yogyakarta: Benteng Pustaka.

Keraf, G. (2016). Diksi dan Gaya Bahasa. Jakarta: Gramedia Pustaka Utama.

Khalidi, S., \& Atan, E. (2017). Unsur Eufemisme dalam Novel Jalan Retak Karya A. Samad Said. Journal of Business and Social Development, 5(1), 88-101.

Nugrahani, F., \& Hum, M. (2014). Metode Penelitian Kualitatif. Solo: Cakra Books.

Puspitasari, F., Sumarwati, \& Suryanto, E. (2019). Pemakaian Eufemisme dalam Surat Kabar Solopos. Jurnal Bahasa, Sastra, dan Pengajarannya, 7(2), 139-148.

Santoso, S. (2016). Majas dalam Novel Semesta Mendukung Karya Ayuwidya. Jurnal Bastra, 2(1).

Saputri, V., Ramadhan, S., \& Asri, Y. (2019). Eufemisme dan Disfemisme dalam Novel Korupsi Karya Pramoedya Ananta Toer. Jurnal Bahasa, Sastra dan Pengajarannya, 12(2), 197-207.

Setiawaty, R., \& Wahyudi, A. (2018). Bentuk dan Fungsi Eufemisme dalam Komentar Akun Facebook Presiden Joko Widodo sebagai Bahan Ajar Bahasa Indonesia. Proceeding of the Urecol, 88-100.

Siswantoro. (2016). Metode Penelitian Sastra. Yogyakarta: Pustaka Pelajar.

Sugiyono. (2018). Metode Penelitian Kuantitatif, Kualitatif, dan R\&D. Bandung: Alfabeta.

Supriyadi, E. (2013). Kajian Bahasa Tabu dan Eufemisme pada Kumpulan Cerpen Senyum Karyamin Karya Ahmad Tohari. Doctoral Dissertation, Universitas.

Sutarman. (2017). Tabu Bahasa dan Eufemisme. Surakarta: Yuma Pustaka.

Tarigan, H. (2013). Pengajaran Gaya Bahasa. Bandung: Angkasa. 